\title{
Assessment of thermal processing contaminant levels in dried and smoked fruits
}

\author{
Magdalena Surma ${ }^{1} \cdot$ Anna Sadowska-Rociek $^{1} \cdot$ Ewa Cieślik $^{1}$
}

Received: 16 January 2018 / Revised: 16 March 2018 / Accepted: 17 March 2018 / Published online: 26 March 2018

(c) The Author(s) 2018

\begin{abstract}
The paper reports the levels of thermal processing contaminants such as polycyclic aromatic hydrocarbons (PAHs), 3-monochloropropane-1,2-diol (3-MCPD) and acrylamide (AA) in 28 dried (raisins, dates, apricots, cranberries and plums-prunes) and 15 smoked (pears, apples and plums) fruit samples from Polish retail market. Analytes were determined using GCSIM-MS, after being subjected to modified QuEChERS method. The results showed that almost all PAHs were detected in smoked fruit samples, except of dibenzo(a,h)anthracene, which was identified only in 4 from 15 samples. In case of dried fruits they were quantified in all 28 samples. The highest 3-MCPD content in group of smoked fruits was noted in plums $\left(70.9 \mu \mathrm{g} \mathrm{kg}^{-1}\right)$, while in dried fruits for raisins $(33.0 \mu \mathrm{g} \mathrm{kg}-1)$. The lowest amount, with the value of $9.3 \mu \mathrm{g} \mathrm{kg}^{-1}$ was identified in dried raisins and cranberry. In the group of smoked fruits, the lowest AA amount was found in apple sample (19.6 $\mu \mathrm{g}$ $\left.\mathrm{kg}^{-1}\right)$ and the highest in sample of plums $\left(730 \mu \mathrm{g} \mathrm{kg}^{-1}\right)$ followed by pears sample $\left(696 \mu \mathrm{g} \mathrm{kg}^{-1}\right)$. The AA concentration in dried fruits ranged from $<\mathrm{LOQ}$ for dates sample, raisins, and cranberry samples to $141 \mathrm{\mu g} \mathrm{kg}^{-1}$ for plums sample in our best knowledge, the present paper is the first study concerning the level of the contamination by these heat-induced compounds in such a diversity of foodstuffs such as dried and smoked fruits.
\end{abstract}

Keywords Acrylamide · 3-Monochloropropane ${ }^{-1}, 2$-diol $\cdot$ Polycyclic aromatic hydrocarbons $\cdot$ Dried and smoked fruits QuEChERS method · GC-SIM-MS

\section{Introduction}

Dried and smoked fruits are rich in vitamins A, C, E, K, B6, and minerals such as potassium, calcium, magnesium and phosphorus and polyphenols, therefore, they are getting more and more popular among consumers. As a result of drying, the fruits lose moisture, thereby increasing the content of nutrients and vitamins in the remaining mass. Dried fruits also contain significant amounts of easily digestible carbohydrates, which are a very good source of energy. Due to high fibre content, they stimulate intestinal peristalsis, and the presence of pectin causes a feeling of satiety. Dried fruits are considered to have antioxidant properties inhibiting the action of harmful free radicals. They show high calorific

Magdalena Surma

m.surma@ur.krakow.pl

1 Faculty of Food Technology, Malopolska Centre of Food Monitoring, University of Agriculture in Krakow, ul. Balicka 122, 30-149 Kraków, Poland value (250-300 kcal $100 \mathrm{~g}^{-1}$ of fruit) due to the low water content of $15-30 \%$ [1].

Several types of drying methods and drying equipments-each best suited for particular foodstuffs-are commonly used to remove moisture from a wide variety of food products. Natural sun drying of crops is still practiced for certain fruits such as plums, apricots, grapes and dates; other techniques involve atmospheric dehydration processes, used for apples, plums, herbs and several vegetables; continuous processes such as tunnel, belt-trough, fluidized-bed and foam-mat drying that are mainly used for vegetables. Spray drying is suitable for fruit juice concentrates, and vacuum dehydration processes are useful for low moisture/ high sugar fruits such as peaches, pears and apricots. The selection of an appropriate dryer/drying method depends on the type of raw material and its properties, the restriction on the operating conditions, and the desired characteristics of dried product and budget. There are three main types of drying processes: sun and solar drying, atmospheric drying including batch or continuous (kiln, tower and cabinet dryers, tunnel, belt, belt-trough, fluidized-bed, explosion-puff, 
foam-mat, spray, drum and microwave), and subatmospheric dehydration (freeze drying and vacuum shelf/belt/drum) [2] . Sun drying is one of the oldest preservative techniques. It is a slow, gentle process whose benefits more than compensate for its time-intensive nature-especially when compared to modern mechanical drying methods [3]. In vacuum drying, the product is heated by steam, conduction (hot oil, heated elements, etc.) or radiation while under low pressure. This drying process may offer product-specific advantages such as low-temperature drying and low oxidation. In drum drying, heat is transferred to the material by conduction with heated revolving drums. Typically, the temperature of the process approaches the boiling point of water and the process time is in the order seconds. Spray drying is the transformation of a fluid into a dry particulate by spraying in a hot medium. Hot air spray drying takes place at temperatures between 150 and $200{ }^{\circ} \mathrm{C}$ [2].

Another method of some food preserving is smoking, which not only inhibits the growth of microorganisms, but also serves to improve taste and preserve nutritional values. This simple method of fixing consists in the action of gases and vapours arising in the process of incomplete combustion of plant substances (mainly wood) on food [4]. Since the beginning of traditional, uncontrolled burning of biomass, the technique of smoking food has been improved until it became a food technology process. There are a number of ways of classifying smoking processes based on the temperature of the smoke, the location of smoke generation with respect to the position of the foodstuff, and the device used for generating smoke [5]. The different smoking methods are classified in three main groups: cold $\left(16-22{ }^{\circ} \mathrm{C}\right)$, warm $\left(22-40{ }^{\circ} \mathrm{C}\right)$ and hot $\left(40-90^{\circ} \mathrm{C}\right)$, depending of the temperature used [4]. Fruit arranged in layers (plums) or cut into quarters or slices (apples, pears) are subjected to a process of smoking in hot smoke [6].

However, due to the use of high temperature processes dried or smoked fruits can be contaminated with the socalled "thermal processing contaminants" such as polycyclic aromatic hydrocarbons (PAHs), chloropropanols (e.g. 3-monochloropropane-1,2-diol, 3-MCPD) and product of Maillard reaction-acrylamide (AA, 2-propenamide). All aforementioned compounds are formed during heat processing of food although the precursors and mechanisms of their formation are different. Their common feature is that all of them are considered as probably and potentially carcinogenic to humans. According to the International Agency for Research on Cancer (IARC), acrylamide was classified as probably carcinogenic to human (group 2A), whereas 3-MCPD was classified as possibly carcinogenic to human (group 2B) [7, 8]. PAHs were classified in both groups 2A and $2 \mathrm{~B}$ and additionally group 3 (not classifiable as to its carcinogenicity to humans), and benzo(a)pyrene in group 1 (carcinogenic to humans) $[9,10]$.
The human organism may be exposed to PAHs through inhalation of polluted air or cigarette smoke together with dietary intake represents the major one [11]. Food can be contaminated by PAHs that are present in air, soil or water or they might be formed during thermal processing of food (drying, smoking, grilling, roasting, frying). In general, PAHs are not present individually but in mixtures. According to Scientific Committee on Food, 15 (benzo(a) pyrene- $\mathrm{BaP}$, benzo(a)anthracene-BaA, dibenzo(a,h) anthracene-DBahA, benzo(b)fluoranthene-BbFl, benzo(j)fluoranthene- $\mathrm{BjFl}$, benzo(k)fluoranthene- $\mathrm{BkFl}$, benzo(g,h,l)perylene-BghlPl, chrysene, cyclopenta(c,d) pyrene $\mathrm{CP}$, dibenzo(a,e)pyrene-DBaeP, dibenzo(a,h)pyrene-DBahP, dibenzo(a,i)pyrene-DBaiP, dibenzo(a,l) pyrene-DBalP indeno(1,2,3,-c,d)pyrene-IP, 5-methylchrysene-5-MC) PAHs showed clear evidence of mutagenicity/genotoxicity in somatic cells in experimental animals in vivo. In European Union, as PAHs indicator in food, the sum of four of them (4 PAHs) including benzo(a)anthracene, chrysene, benzo(b)fluoranthene, and benzo(a)pyrene has been designated [12]. Until this date, maximum levels were established only for several groups of food, mainly for smoked meat and smoked meat products and food based on cereals. What is more, the Scientific Committee on Food (SCF) concluded that it was not possible to establish a threshold level below which risk would be insignificant, and therefore a Tolerable Daily Intake (TDI) could not be set for PAHs. Consequently, it recommended that exposures to PAHs from food should be as low as reasonably achievable.

In case of 3-MCPD, it can be formed in food via three different pathways: acid hydrolysis, heat processing (including smoking), and from decomposition of 3-MCPD esters. Several studies about the mechanism of its formation were performed, anyhow a full review on the occurrence and the formation mechanisms governing of 3-MCPD has been presented by Hamlet et al. [13]. The Scientific Committee on Food of the European Commission established a tolerable daily intake (TDI) at $0.8 \mu \mathrm{g} \mathrm{kg}^{-1}$ body weight (bw) [14].

Acrylamide is one of the neo-formed contaminants (NFCs), produced in food during manufacturing or home cooking. The major pathway for its formation in food is the Maillard reaction that occurs by a condensation of the amino group of the asparagine and the carbonyl group of reducing sugars during heating $[15,16]$. Processing of carbohydraterich food such as baking, frying or roasting can result in AA formation in amounts of milligram per kilo range. The average intake via food for the general population has been estimated by Joint FAO/WHO Experts Committee on Food Contaminants. For the inhabitants of each country, these values have been also assumed by different national organizations. A daily intake of $1 \mu \mathrm{g} \mathrm{kg}^{-1}$ bodyweight was estimated by JECFA for an average consumer, which could rise to $4 \mu \mathrm{g}$ $\mathrm{kg}^{-1}$ bodyweight for consumers of specific food items. Many 
studies indicate that its neurotoxic properties in animals and humans, and that it is a reproductive toxicant and germ cell mutagen in animals [17].

Wherefore looking for an effective complex technique for the simultaneous sample preparation for the determination of all aforementioned contaminants, we decided to implement the QuEChERS approach. This methodology shows certain advantages over traditional analysis as it requires only a small amount of reagents, and a sample clean-up is achieved in a single step instead of a series of time-consuming solvent extraction. It can be a new concept in view of its quickness, easiness, cheapness, effectiveness, ruggedness and safeness. As yet, this approach has shown its usefulness in the analysis of PAHs, 3-MCPD and AA in food [18-20]. However, to our best knowledge, the possibility of QuEChERS application for simultaneous sample preparation in the PAHs, 3-MCPD and AA analysis has still remained unexplored.

In view of the persistence of PAHs, 3-MCPD and AA in food and their significant toxicity, the control of these compounds in food seems to be necessary. Therefore, the aim of this study was to assess the levels of contamination by polycyclic aromatic hydrocarbons, 3-monochloropropane-1,2-diol and acrylamide in dried and smoked fruits. The analysed dried and smoked fruits samples originated from Polish retail market. Eight types of fruits collected for the study were as follows: dried dates (4 products), apricots (6 products), raisins (6 products), cranberries (6 products), plums (prunes) (6 products); smoked pears ( 5 products), apples (5 products) and plums (5 products).

\section{Materials and methods}

\section{Chemicals and reagents}

EPA 525 PAH Mix-B, anthracene $\mathrm{d}_{10}\left(\mathrm{SS}_{1}\right)$, chrysene $\mathrm{d}_{12}$ $\left(\mathrm{IS}_{1}\right.$ ), acrylamide (AA) purum $\geq 98 \%$ (GC), 3-monochloropropane-1,2-diol (3-MCPD), 3-monochloropropane1,2-diol-d ${ }_{5}\left(3-\right.$ MCPD-d $\left._{5}, \mathrm{IS}_{2}\right), 3$-monobromopropane-1,2-diol (3-MBPD, $\mathrm{SS}_{2}$ ), acrylamide- $\mathrm{d}_{3}$ standard solution $\left(\mathrm{IS}_{3}\right), \mathrm{N}, \mathrm{O}$ bis(trimethylsilyl)trifluoroacetamide (BSTFA), phenylboronic acid (PBA), were obtained from Sigma-Aldrich Chemie $\mathrm{GmbH}$, Germany and Saint Luis, Missouri, USA. Magnesium sulphate anhydrous p.a. and sodium chloride p.a., were purchased from POCh SA, Poland. Acetonitrile and hexane, HPLC grade for liquid chromatography LiChrosolve ${ }^{\circledR}$ was purchased from Merck KGaA, Germany. PSA (primary and secondary amine) SPE Bulk Sorbent derived from Agilent Technologies, USA. A sodium chloride solution was of $200 \mathrm{mg}$ $\mathrm{mL}^{-1}(20 \%)$ was prepared in deionised water. Deionised water $(18 \mathrm{M} \Omega)$ was produced by a Milli-Q system (Millipore, USA). Stock, intermediate and working standard solutions of AA $\left(1 \mu \mathrm{g} \mathrm{mL}{ }^{-1}\right)$, PAHs $\left(1 \mu \mathrm{g} \mathrm{mL}^{-1}\right)$, chrysene- $\mathrm{d}_{12}\left(1 \mu \mathrm{gL}^{-1}\right)$ were prepared in hexane and acrylamide- $\mathrm{d}_{3}\left(10 \mu \mathrm{gL}^{-1}\right)$, and anthracene- $\mathrm{d}_{10}\left(1 \mu \mathrm{g} \mathrm{mL}^{-1}\right)$ in acetonitrile. Intermediate and working standard solutions of chloropropanols $\left(2 \mu \mathrm{g} \mathrm{mL} \mathrm{m}^{-1}\right)$ were prepared in a $20 \% \mathrm{NaCl}$ solution. A PBA solution was prepared by dissolving $5 \mathrm{~g}$ of PBA in a $20 \mathrm{~mL}$ mixture of acetone and water $(19: 1, \mathrm{v} / \mathrm{v})$.

\section{Instrumentation}

The GC application were carried out on a Varian 4000 GC/MS (Varian, Inc., USA) system consisted of 3800 gas chromatograph and 4000 Ion Trap MS detector. The column was a DB-5MS column $(30 \mathrm{~m} \times 0.25 \mathrm{~mm} \times 0.25 \mu \mathrm{m}$; Agilent Technologies, USA). The GC oven was operated with the following temperature program: initial temperature $50{ }^{\circ} \mathrm{C}-3{ }^{\circ} \mathrm{C} \min ^{-1}-100{ }^{\circ} \mathrm{C}-25{ }^{\circ} \mathrm{C} \mathrm{min}{ }^{-1}-250{ }^{\circ} \mathrm{C}$ (5.0 min) for AA, initial temperature $60^{\circ} \mathrm{C}(1.0 \mathrm{~min})-6{ }^{\circ} \mathrm{C}$ $\min ^{-1}-190{ }^{\circ} \mathrm{C}(1 \mathrm{~min})-30{ }^{\circ} \mathrm{C} \min ^{-1}-280{ }^{\circ} \mathrm{C}(6.0 \mathrm{~min})$ for 3-MCPD, and initial temperature $50^{\circ} \mathrm{C}(1 \mathrm{~min})-15^{\circ} \mathrm{C}$ $\mathrm{min}^{-1}-320^{\circ} \mathrm{C}$ (6.0 min) for PAHs. Helium 5.0 (Linde Gas, Poland) was used as the GC carrier gas at a flow rate of $1.0 \mathrm{~mL} \mathrm{~min}{ }^{-1}$. The autosampling injector was CP-1177 Split/Splitless Capillary Injector, with a temperature of $270{ }^{\circ} \mathrm{C}$ for PAHs, $180{ }^{\circ} \mathrm{C}$ for 3 -MCPD, and $250{ }^{\circ} \mathrm{C}$ for AA, with the volume of $1.0 \mu \mathrm{L}$ for all standards and samples. Each injection was repeated three times. The ion trap mass spectrometer was operated on the internal ionisation mode, scan from $\mathrm{m} / \mathrm{z} 45$ to 500 . Analysis was conducted in the selected ion monitoring mode (SIM), based on the quantitative ions. Analysed compounds were identified according to their qualitative ions and retention times summarized in Table 1 for PAHs, PBA derivatives of 3-MCPD and BSTFA derivatives of AA. The trap and the transfer line temperatures were set at 180 and $230{ }^{\circ} \mathrm{C}$, respectively, for all tested analytes. The analyses were carried out with the solvent delay of $7 \mathrm{~min}$. The emission current of the ionisation filament was set at $15 \mu \mathrm{A}$. Acquisition and processing data were performed using Varian Star Workstation software and NIST 2.0 library (National Institute of Standards and Technology, Gaithersburg, Maryland, USA).

MS1 Minishaker (IKA, Königswinter, Germany), MPW 350 R Centrifuge (MPW Med. Instruments, Warsaw, Poland) were employed during the sample preparation. Accublock ${ }^{\mathrm{TM}}$ (Labnet, Edison, NJ, USA) with nitrogen 5.0 (Linde Gas, Munchien, Germany) was used to evaporate the solvent, incubate, and concentrate the extracts.

\section{Simultaneous sample preparation method for PAHs, 3-MCPD and AA determination}

The sample extraction, clean-up, analysis and the solutions of calibration standards for all analytes were prepared according to our previous reports $[19,20]$. 
Table 1 Retention times and ions used in GC-MS analyses

\begin{tabular}{|c|c|c|c|}
\hline$R_{\mathrm{t}}$ & Compound & $\begin{array}{l}\text { Quantifi- } \\
\text { cation ion }\end{array}$ & Confirmation ions \\
\hline \multicolumn{4}{|l|}{ PAHs } \\
\hline 9.66 & Acenaphthylene & 152.1 & $151.1,151.3,153.1$ \\
\hline 10.76 & Fluorene & 166.1 & $164.1,165.1,165.3$ \\
\hline 12.31 & Phenanthrene & 178.1 & $166.1,178.2,179.1$ \\
\hline 12.36 & Anthracene $\mathrm{d}_{10}\left(\mathrm{IS}_{1}\right)$ & 188.0 & $188.1,177.9,189.2$ \\
\hline 12.39 & Anthracene & 178.1 & $165.1,178.2,179.1$ \\
\hline 14.59 & Pyrene & 202.1 & $200.1,202.3,203.1$ \\
\hline 16.53 & Benzo(a)anthracene & 228.1 & $226.1,228.3,229.1$ \\
\hline 16.58 & Chrysene $\mathrm{d}_{12}\left(\mathrm{SS}_{1}\right)$ & 240.1 & $240.2,239.2,241.2$ \\
\hline 16.83 & Chrysene & 228.1 & $226.1,228.3,229.1$ \\
\hline 18.19 & Benzo(b)fluoranthene & 252.1 & $250.1,253.1,253.3$ \\
\hline 18.24 & Benzo(k)fluoranthene & 252.1 & $250.1,250.4,253.1$ \\
\hline 18.74 & Benzo(a)pyrene & 252.1 & $250.1,250.3,253.2$ \\
\hline 21.17 & Indeno(c,d)pyrene & 276.1 & $274.1,277.1,277.5$ \\
\hline 21.26 & Dibenzo(a,h)anthracene & 278.2 & $276.0,276.5,279.1$ \\
\hline 21.86 & Benzo(g,h,i)perylene & 276.0 & $274.1,276.4,277.0$ \\
\hline \multicolumn{4}{|c|}{ 3-MCPD ${ }^{\mathrm{a}}$} \\
\hline 17.23 & 3-MCPD & 147.1 & $93.0,149.1,201.0$ \\
\hline 17.29 & 3-MBPD $\left(\mathrm{SS}_{2}\right)$ & 147.0 & $91.0,146.1,196.0$ \\
\hline 19.09 & $3-\mathrm{MCPD}-\mathrm{d}_{5}\left(\mathrm{IS}_{2}\right)$ & 150.0 & $91.0,146.1,241.9$ \\
\hline \multicolumn{4}{|l|}{$\mathrm{AA}^{\mathrm{b}}$} \\
\hline 8.81 & AA & 128.1 & $128.2,129.2,131.1$ \\
\hline 8.65 & AA-d ${ }_{3}\left(\mathrm{IS}_{3}\right)$ & 132.1 & $132.2,204.2,220.1$ \\
\hline
\end{tabular}

$R_{t}$ retention time, $P A H s$ polycyclic aromatic hydrocarbons, 3-MCPD 3-monochloropropane-1,2-diol, 3-MBPD 3-monobromopropane1,2-diol, $I S$ internal standard, $S S$ syringe standard, $A A$ acrylamide

${ }^{a}$ Analysed as PBA (phenylboronic acid) derivatives (separate GC-MS analysis)

${ }^{\mathrm{b}}$ Analysed as BSTFA (N,O-bis(trimethylsilyl)trifluoroacetamide) derivatives (separate GC-MS analysis)

\section{Extraction and clean-up the sample}

The extraction process was conducted as follows: $1.5 \mathrm{~g}$ of a representative portion (previously prepared pulp) of fruits were weighted into a $50-\mathrm{mL}$ centrifuge tube and spiked with all 3 [IS $1(20 \mu \mathrm{L}), \mathrm{IS}_{2}(25 \mu \mathrm{L})$ and $\left.\operatorname{IS}_{3}(5 \mu \mathrm{L})\right]$ internal standards, mixed and left to stand for $15 \mathrm{~min}$ at room temperature prior to extraction. Then $15 \mathrm{~mL}$ of acetonitrile were added and the mixture was vigorously shaken for $1 \mathrm{~min}$. Next, $1.5 \mathrm{~g} \mathrm{NaCl}$ and $6 \mathrm{~g} \mathrm{MgSO}_{4}$ were added, and the tube was shaken vigorously for $1 \mathrm{~min}$, and centrifuged for $15 \mathrm{~min}$ at $8700 \mathrm{RCF}$ (relative centrifugal force). $9 \mathrm{~mL}$ of the supernatant was transferred into a PP $15 \mathrm{~mL}$ tube containing $0.23 \mathrm{~g}$ of PSA, and $1.4 \mathrm{~g} \mathrm{MgSO}_{4}$. After $30 \mathrm{~s}$ shaking and $5 \mathrm{~min}$ centrifugation at $5000 \mathrm{RCF}$ $6 \mathrm{~mL}$ of extract divided for three portions for $2 \mathrm{~mL}$ was transferred into 4-mL tubes and evaporated under $\mathrm{N}_{2}$ stream to dryness.

\section{PAHs analysis}

The final residues (of $2 \mathrm{~mL}$ supernatant after evaporation) were dissolved in $1 \mathrm{~mL}$ of hexane, and the syringe standard $\left(\mathrm{SS}_{1} 20 \mathrm{~mL}\right)$ was added. The mixture was shaken and transferred into a autosampler vial and $1 \mu \mathrm{L}$ of extract was analysed by GC-SIM-MS.

\section{3-MCPD analysis}

The final residues (of $2 \mathrm{~mL}$ supernatant after evaporation) were dissolved in $100 \mu \mathrm{L}$ of $20 \% \mathrm{NaCl}$ aqueous solution and $25 \mu \mathrm{L} 3$-MBPD solution plus $25 \mu \mathrm{L}$ PBA solutions were added. The mixture was heated in a aluminium inset of Accublock ${ }^{\mathrm{TM}}$. The reaction was conducted for $20 \mathrm{~min}$ in $90^{\circ} \mathrm{C}$. After cooling, $0.5 \mathrm{~mL}$ hexane was added, the mixture was shaken vigorously and $200 \mu \mathrm{L}$ of upper hexane layer was transferred into an insert of an autosampler vial and $1 \mu \mathrm{L}$ of extract was analysed by GC-SIM-MS.

\section{AA analysis}

The final residues (of $2 \mathrm{~mL}$ supernatant after evaporation) were dissolved in $500 \mu \mathrm{L}$ of $\mathrm{MeCN} .400 \mu \mathrm{L}$ of the extract was placed in $1.5 \mathrm{~mL}$ screw cap vial containing $90 \mu \mathrm{L}$ of BSTFA and was heated in $70^{\circ} \mathrm{C}$ for $1 \mathrm{~h}$. After cooling, 200 $\mu \mathrm{L}$ of hexane was added and liquid-liquid extraction was performed for $1 \mathrm{~min}$ using a vortex. Upper hexane layer in an amount of $100 \mu \mathrm{L}$ was transferred into an autosampler vial insert and $1 \mu \mathrm{L}$ of extract was analysed by GC-SIM-MS.

Reagent blank samples were prepared according the appropriate procedure for all tested analytes. Each samples (real and blanks) were prepared in triplicate.

\section{Statistical analysis method}

The results are presented as the mean values \pm standard deviation (SD). The data were analysed using one-way ANOVA followed by Fisher's post hoc test. $p$ values $<0.05$ were considered as significant. All analyses were performed using Statistica 12.0 software (Stat-Soft Inc., Tulsa, OK, USA).

\section{Results and discussion}

\section{PAHs content}

The content of analysed polycyclic aromatic hydrocarbons in investigated samples was presented in Table 2 in supplementary materials, and the corresponding LOD and LOQ values in Table 3. PAHs were detected in all 28 dried fruit samples. PAHs content was varied and depended on the fruit type. The highest content in dried fruits was found in raisins 
(105 and $113 \mu \mathrm{g} \mathrm{kg}^{-1}$ ) and dates $\left(85.2 \mu \mathrm{g} \mathrm{kg}^{-1}\right)$. In the dried samples, mainly the so-called "light" PAHs (acenaphthylene, fluorene, anthracene, phenanthrene, pyrene, chrysene, benzo(a)anthracene, benzo(b)fluoranthene, benzo(k)fluoranthene) were present, and their content ranged from 1.0 to $60.5 \mu \mathrm{g} \mathrm{kg}^{-1}$. Acenaphthylene, fluorene, phenanthrene and pyrene were quantified in all analysed dried fruit samples. The highest amount was reported for phenanthrene and ranged from 8.1 to $60.5 \mu \mathrm{g} \mathrm{kg}^{-1}$, whereas the lowest for acenaphthylene and ranged from 1.8 to $8.1 \mu \mathrm{g} \mathrm{kg}^{-1}$. PAHs markers (benzo(a)pyrene, chrysene, benzo(a)anthracene and benzo(b)fluoranthene) were not identified in most of the analysed dried fruit samples. They were detected only in three date samples and one sample of raisins. The highest content of chrysene was in date sample $\left(3.0 \mu \mathrm{g} \mathrm{kg}^{-1}\right)$, while for benzo(a)anthracene in the sample of raisin $\left(1.3 \mu \mathrm{g} \mathrm{kg}^{-1}\right)$.

Almost all analysed PAHs were detected in investigated smoked fruit samples, except of dibenzo(a,h)anthracene, which was identified in 4 from 15 samples. The highest content was observed for phenanthrene in the range of 656-4931 $\mathrm{g} \mathrm{kg}^{-1}$ for pears, 38.9-9335 $\mathrm{g} \mathrm{kg} \mathrm{k}^{-1}$ for apples and $1225-5454 \mu \mathrm{g} \mathrm{kg}^{-1}$ for plums, and also for pyrene in the range of $911-4006 \mu \mathrm{g} \mathrm{kg}^{-1}, 29.7-4542 \mu \mathrm{g} \mathrm{kg}^{-1}$ and $1078-2440 \mathrm{~g} \mathrm{~kg}^{-1}$ for pears, apples and plums, respectively. The lowest content was noted for benzo(k)fluoranthene in pears (15.5-73.5 $\mu \mathrm{g} \mathrm{kg}^{-1}$ ) and in apples (36.6-50.8 $\mu \mathrm{g} \mathrm{kg}^{-1}$ ) and benzo(g,h,i)perylene in plums $\left(15.5-50.5 \mu \mathrm{g} \mathrm{kg}^{-1}\right)$. The sum of 4 PAHs, which is an indicator of the presence of PAHs in food, was the highest in two smoked pears samples with the values equal to 1677 and $1822 \mu \mathrm{g} \mathrm{kg}^{-1}$. The smallest amount of 4 PAHs was found in the sample of smoked apples and was at $13.6 \mu \mathrm{g} \mathrm{kg}^{-1}$. A comparison of the 4 PAHs

Table 2 LOD and LOQ for all investigated analyses

\begin{tabular}{lll}
\hline Compound & LOD $\left(\mu \mathrm{gg}^{-1}\right)$ & $\mathrm{LOQ}\left(\mu \mathrm{g} \mathrm{kg}^{-1}\right)$ \\
\hline Acenaphthylene & 0.09 & 0.27 \\
Fluorene & 0.11 & 0.33 \\
Phenanthrene & 0.08 & 0.24 \\
Anthracene & 0.09 & 0.27 \\
Pyrene & 0.10 & 0.30 \\
Benzo(a)anthracene & 0.14 & 0.42 \\
Chrysene & 0.15 & 0.45 \\
Benzo(b)fluoranthene & 0.16 & 0.48 \\
Benzo(k)fluoranthene & 0.18 & 0.54 \\
Benzo(a)pyrene & 0.19 & 0.57 \\
Indeno(c,d)pyrene & 0.19 & 0.57 \\
Dibenzo(a,h)anthracene & 0.20 & 0.60 \\
Benzo(g,h,i)perylene & 0.26 & 0.78 \\
3- Monochloropropane-1,2-diol & 3.10 & 9.30 \\
Acrylamide & 3.02 & 9.06
\end{tabular}

$L O D$ limit of detection, $L O Q$ limit of quantification content in dried and smoked plums and in all investigated dried and smoked products showed a statistically significant difference. Total PAH content in dried fruits was in the range of $23.1-113 \mu \mathrm{g} \mathrm{kg}^{-1}$. However, in smoked fruits it ranged from 94.9 to $20,562 \mu \mathrm{g} \mathrm{kg}^{-1}$. In smoked fruits, the total PAH level was statistically significantly higher than in dried fruits. The total PAH contents in dried and smoked plums were significantly different as well. Among the dried fruits, the lowest amount of total PAHs was found in raisins from producer one $\left(23.1 \mu \mathrm{g} \mathrm{kg}^{-1}\right)$ and the highest in raisins from other one $\left(113 \mu \mathrm{g} \mathrm{kg}^{-1}\right)$. While in the group of smoked fruits the lowest total PAH concentration was detected in the apple sample purchased on the market square $\left(94.9 \mu \mathrm{g} \mathrm{kg}^{-1}\right)$, and the highest also by apple, but purchased from another farmer $\left(20,562 \mu \mathrm{g} \mathrm{kg}^{-1}\right)$.

No correlation was found between PAH content in investigated fruit samples and their producers.

The PAH content in the corresponding fresh fruit has been analysed by Paris et al. [21], who reviewed the occurrence of PAHs in fruits and vegetables. The levels of 15 PAHs in 20 fruits from eight studies were collected. They concluded that the PAH level in investigated fruits coming from polluted environments (soil, water and air) remained generally low. The sum of the eight heavy PAHs with molecular weights from 228 to $278 \mathrm{~g} \mathrm{~mol}^{-1}$ in apples was in the range 0 to $3.82 \mu \mathrm{g} \mathrm{kg}^{-1}$, in pears from 0 to $0.01 \mu \mathrm{g} \mathrm{kg}^{-1}$, and in apricots from 0.15 to $0.37 \mu \mathrm{g} \mathrm{kg}^{-1}$. For plums, only a few PAHs was identified below the decimal parts of $\mu \mathrm{g}$ [21]. The results of the research show that drying process resulted in the PAHs presence in fruits, but definitely less than smoking process. Average PAH content in dried fruits was at the level of $65.6 \mu \mathrm{g} \mathrm{kg}^{-1}$, and remained low compared to a few thousands of $\mu \mathrm{g} \mathrm{kg}^{-1}$ in smoked fruits. These data indicate a great concern, especially in the case of smoked fruits. Smoked fruits could have been treated under conditions where the smoking temperature was above $425^{\circ} \mathrm{C}$, thus it was favoured to produce a multi-ring aromatic hydrocarbons. Considering that smoked fruits are often used as additives to traditional foods such as meats, or pates that are willingly consumed in Eastern Europe, these products pose a great threat to human health. The maximum 4 PAHs concentration established by EU for the only smoked foodstuffs (bivalve molluscs) was set at $35 \mu \mathrm{g} \mathrm{kg}^{-1}$ [22]. For the dried fruit tested, the sum of 4 PAHs was $0 \mu \mathrm{g} \mathrm{kg}^{-1}$, except of four samples. The average content in smoked fruit was $981 \mu \mathrm{g} \mathrm{kg}^{-1}$, which means that these results far exceed the set value. This confirms the need for further research in this area and the need to set a maximum PAH content in dried and smoked fruits to protect human health. It also seems necessary to inform consumers about the potential health effects of regular consumption this type of foodstuffs. However, there was some inconvenience with comparing the results of analysis with another data because to our best 


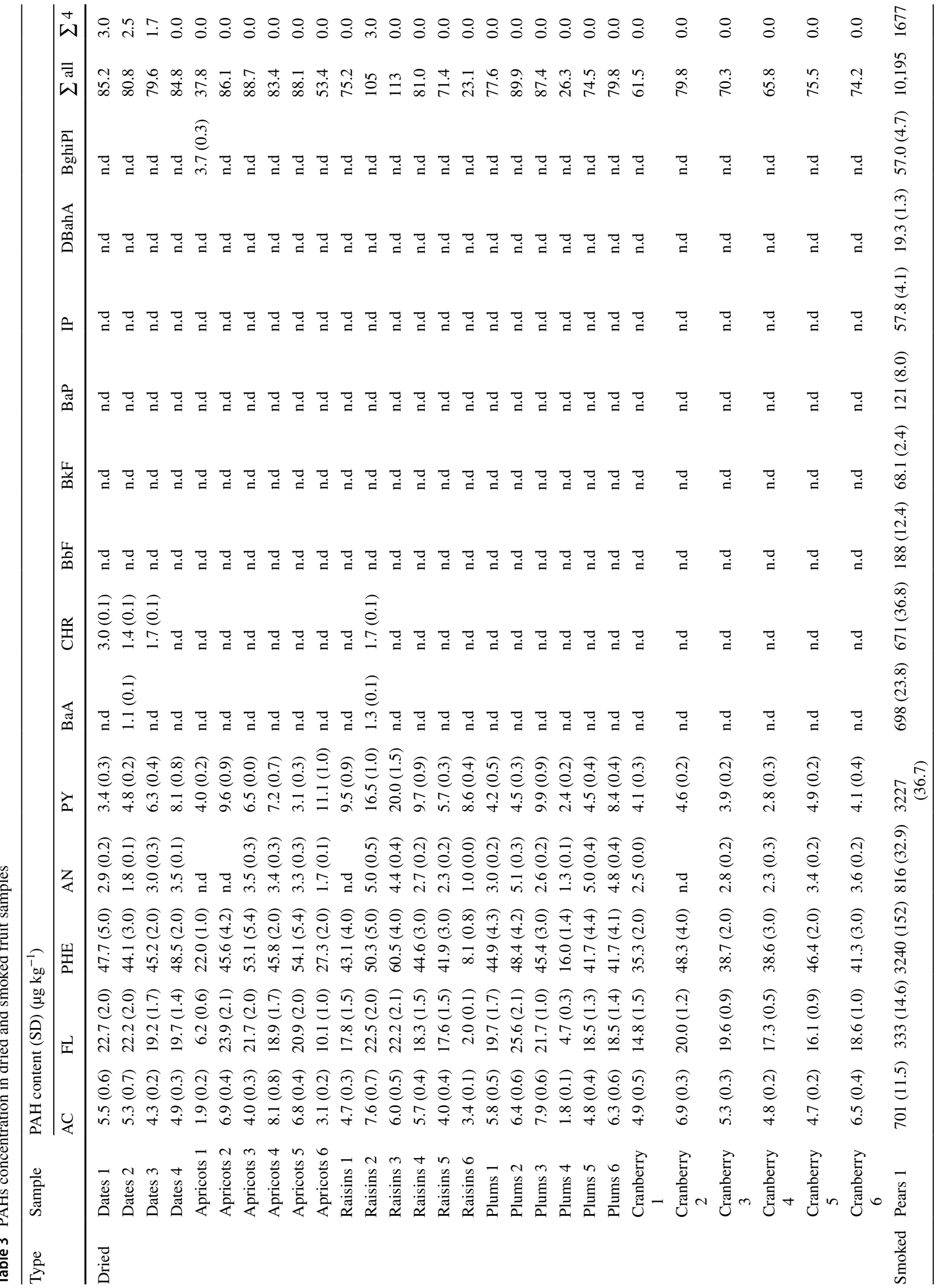




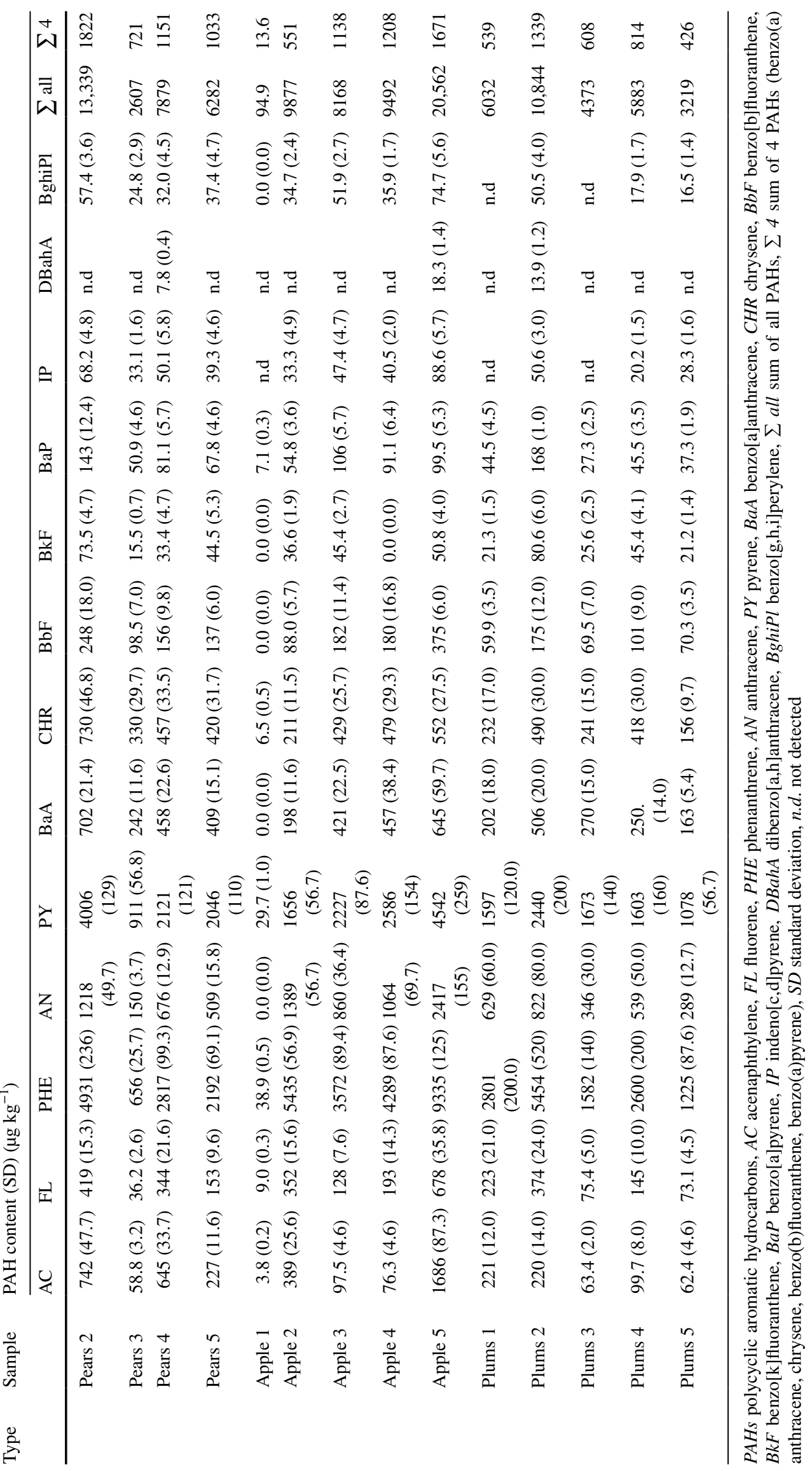


knowledge, no other studies regarding PAH content in dried and smoked fruits have been reported in the literature with the exception of two reports. The first one was published by Food Safety Authority in Ireland [23], and concerned 11 samples of dried vine fruits, other dried fruits and dried tomatoes. Upper bound levels of SCF-15 ranged from 0.54 to $1.12 \mu \mathrm{g} \mathrm{kg}^{-1}$ fresh weight, and chrysene, benzo(a)anthracene and benzo(b)fluoranthene being the most abundant congeners. The second one was published 2 years later by EFSA [24]. According to this report, 264 dried fruit samples from eight countries (Belgium, the Czech Republic, France, Germany, Greece, Ireland and United Kingdom) were investigated. Benzo(c)fluorene had the highest mean and maximum concentration at 5.11 and $144 \mu \mathrm{g} \mathrm{kg}^{-1}$, respectively, from all 16 tested PAHs. Benzo(a)pyrene had a mean concentration of only $0.10 \mu \mathrm{g} \mathrm{kg}^{-1}$ with $23 \%$ of the samples showing detectable levels of the substance. The highest mean was recorded for chrysene at $0.91 \mu \mathrm{g} \mathrm{kg}^{-1}$ and the highest maximum for benzo(a)anthracene [24]. Forasmuch, the species of the tested fruits and the presented values are incomparable with the results. Therefore, in this study, we decided to fill out the existing gap in the knowledge about PAHs concentration in dried and smoked fruits.

\section{3-MCPD content}

The content of 3-MCPD determined in all investigated samples was presented in Table 4 . The highest content within dried fruits was observed in raisins sample $\left(33.0 \mu \mathrm{g} \mathrm{kg}^{-1}\right)$, while in smoked fruits, the highest 3-MCPD level was found in plums $\left(70.9 \mu \mathrm{g} \mathrm{kg}^{-1}\right)$. The lowest amount, with the value of $9.3 \mu \mathrm{g} \mathrm{kg}^{-1}$, was identified in dried raisins and cranberry. A comparison of the 3-MCPD content in dried and smoked plums and in all investigated dried and smoked products showed a lack of statistically significant difference and mean values remained close to each other $\left(12.1 \mu \mathrm{g} \mathrm{kg}^{-1}\right.$ for dried fruits and $13.9 \mu \mathrm{g} \mathrm{kg}^{-1}$ for smoked ones). No correlation was found between 3-MCPD content in investigated fruit samples and their producers as well. As far, no EU regulations have been established on maximum levels (MLs) in foodstuffs such as dried and smoked fruits. The only one available refers to hydrolyzed vegetable protein (HVP) and soy sauce and was set at $20 \mu \mathrm{g} \mathrm{kg}^{-1}$. Likewise, no other studies regarding 3-MCPD content in dried and smoked fruits have been reported in the literature. Scientific Report of EFSA treating about analysis of occurrence of 3-monochloropropane-1,2-diol (3-MCPD) in food in Europe [25] neither did not include such a foodstuffs. Hence, it reaffirms the necessity for further research in this area.
Table 4 3-MCPD concentration in dried and smoked fruit samples

\begin{tabular}{|c|c|c|c|c|}
\hline Type & Sample & $\begin{array}{l}\text { 3-MCPD con- } \\
\text { centration } \pm \mathrm{SD} \\
\left(\mu \mathrm{kg}^{-1}\right)\end{array}$ & Mean 3-MCPD & $\begin{array}{l}\text { Mean } \sum \\
\text { 3-MCPD }\end{array}$ \\
\hline \multirow[t]{28}{*}{ Dried } & Dates 1 & $16.8 \pm 1.4$ & 15.6 & $12.1^{\mathrm{b}}$ \\
\hline & Dates 2 & $17.9 \pm 2.1$ & & \\
\hline & Dates 3 & $13.2 \pm 1.3$ & & \\
\hline & Dates 4 & $14.4 \pm 0.9$ & & \\
\hline & Apricots 1 & $11.5 \pm 0.4$ & 3.6 & \\
\hline & Apricots 2 & n.d & & \\
\hline & Apricots 3 & $10.2 \pm 0.2$ & & \\
\hline & Apricots 4 & n.d & & \\
\hline & Apricots 5 & $<\mathrm{LOQ}$ & & \\
\hline & Apricots 6 & $<\mathrm{LOQ}$ & & \\
\hline & Raisins 1 & $16.3 \pm 2.3$ & 14.9 & \\
\hline & Raisins 2 & $<\mathrm{LOQ}$ & & \\
\hline & Raisins 3 & $19.0 \pm 2.0$ & & \\
\hline & Raisins 4 & $11.6 \pm 1.9$ & & \\
\hline & Raisins 5 & $9.3 \pm 0.5$ & & \\
\hline & Raisins 6 & $33.0 \pm 1.5$ & & \\
\hline & Plums 1 & $15.0 \pm 2.2$ & $17.5^{\mathrm{a}}$ & \\
\hline & Plums 2 & $17.1 \pm 1.6$ & & \\
\hline & Plums 3 & $25.4 \pm 1.8$ & & \\
\hline & Plums 4 & $18.8 \pm 1.7$ & & \\
\hline & Plums 5 & $13.5 \pm 0.2$ & & \\
\hline & Plums 6 & $15.2 \pm 1.6$ & & \\
\hline & Cranberry 1 & $10.2 \pm 0.6$ & 10.1 & \\
\hline & Cranberry 2 & $9.8 \pm 0.7$ & & \\
\hline & Cranberry 3 & $9.3 \pm 0.5$ & & \\
\hline & Cranberry 4 & $<\mathrm{LOQ}$ & & \\
\hline & Cranberry 5 & $15.0 \pm 0.8$ & & \\
\hline & Cranberry 6 & $16.2 \pm 0.5$ & & \\
\hline \multirow[t]{15}{*}{ Smoked } & Pears 1 & $15.9 \pm 1.2$ & 6.2 & $13.9^{\mathrm{b}}$ \\
\hline & Pears 2 & $14.9 \pm 0.5$ & & \\
\hline & Pears 3 & n.d & & \\
\hline & Pears 4 & $<\mathrm{LOQ}$ & & \\
\hline & Pears 5 & $<\mathrm{LOQ}$ & & \\
\hline & Apple 1 & $<\mathrm{LOQ}$ & 7.3 & \\
\hline & Apple 2 & $<\mathrm{LOQ}$ & & \\
\hline & Apple 3 & n.d & & \\
\hline & Apple 4 & $18.4 \pm 1.0$ & & \\
\hline & Apple 5 & $18.3 \pm 1.6$ & & \\
\hline & Plums 1 & $28.9 \pm 0.2$ & $28.3^{\mathrm{a}}$ & \\
\hline & Plums 2 & $70.9 \pm 3.2$ & & \\
\hline & Plums 3 & $12.6 \pm 1.8$ & & \\
\hline & Plums 4 & $28.9 \pm 1.3$ & & \\
\hline & Plums 5 & $<\mathrm{LOQ}$ & & \\
\hline
\end{tabular}

Mean values denoted by the different letters are statistically significant $(p<0.05)$

3-MCPD 3-monochloropropano-1,2-diol, $S D$ standard deviation, $L O Q$ limit of quantification, n.d. not detected 


\section{AA content}

The acrylamide content determined in all investigated samples was presented in Table 5. The AA concentration in dried fruits ranged from < LOQ for dates sample, raisins, and cranberry samples to $141 \mu \mathrm{g} \mathrm{kg}^{-1}$ for plums sample. In the group of smoked fruits, the lowest AA amount was found in apple sample $\left(19.6 \mu \mathrm{g} \mathrm{kg}^{-1}\right)$ and the highest in sample of plums $\left(730 \mu \mathrm{g} \mathrm{kg}^{-1}\right)$ followed by pears sample $\left(696 \mu \mathrm{g} \mathrm{kg}^{-1}\right)$. Mean AA content in dried fruits was $21.4 \mu \mathrm{g} \mathrm{kg}^{-1}$, wherein it was not detected in the cranberry and raisins samples. In smoked fruits, mean acrylamide content was $270.7 \mu \mathrm{g} \mathrm{kg}^{-1}$. A comparison of AA content in all investigated dried and smoked products showed a statistically significant difference. The same comparison of acrylamide content in dried and smoked plums revealed a statistically significant difference. Due to the lack of UE regulations on MLs in foodstuffs such as dried and smoked fruits, the obtained AA levels can be only compared with the available literature on dried prunes. Even in EC Recommendation 2013/647/EU [26] indicative AA values for foodstuffs comparable with tested samples were not found. De Paola et al. [27] showed acrylamide content ranged from 14.74 to $124.26 \mu \mathrm{g} \mathrm{kg}^{-1}$, which is very similar to our results $\left(22.08-141.54 \mu \mathrm{g} \mathrm{kg}^{-1}\right)$. Zilić [28] also reported the AA content range from 19 to $146 \mu \mathrm{g}$ $\mathrm{kg}^{-1}$ being in agreement with our results. Becalski et al. [29] noted the values in a range of $58-332 \mu \mathrm{g} \mathrm{kg}^{-1}$ for pitted prunes. The lowest amount of acrylamide was detected by Kukurova et al. [30], from 19 to $46 \mu \mathrm{g} \mathrm{kg}^{-1}$. The differences in mentioned results can result from different brands of investigated foodstuffs. In De Paola et al. [27] research that involved dried raisins, the received value was below LOD, while in our tests we received mean the AA content values equal to $4.44 \mu \mathrm{g} \mathrm{kg}^{-1}$. No correlation was found between the AA amount in investigated fruit samples and their producers.

\section{General considerations}

Analysing the obtained results it should be underlined the high variability of the content of the examined contaminants. Most likely, this is due to the different processing conditions of the tested dried and smoked fruits. Nevertheless, the finding of the correlation between the content of individual pollutants and the processing conditions is not possible because the producers have not provided information on this subject by sheltering with trade secrets.

It is well known that some technological operations may influence on (partially or totally) the quality of products. Therefore, a lot of changes in physical, chemical and/or biological features of foodstuffs may occur during food processing, storage and distribution [31]. The aim of food drying is the decrease of the amount of free-water to inhibit deteriorative processes, which are mainly resulted from microbial
Table 5 AA concentration in dried and smoked fruit samples

\begin{tabular}{|c|c|c|c|c|}
\hline Type & Sample & $\begin{array}{l}\text { AA concentra- } \\
\text { tion } \pm \mathrm{SD}(\mu \mathrm{g} \\
\left.\mathrm{kg}^{-1}\right)\end{array}$ & Mean AA & Mean $\sum$ AA \\
\hline \multirow[t]{28}{*}{ Dried } & Dates 1 & $50.9 \pm 5.2$ & \multirow[t]{4}{*}{23.0} & \multirow[t]{28}{*}{$21.4^{\mathrm{c}}$} \\
\hline & Dates 2 & $21.2 \pm 2.2$ & & \\
\hline & Dates 3 & $20.1 \pm 1.9$ & & \\
\hline & Dates 4 & n.d & & \\
\hline & Apricots 1 & $100 \pm 5.0$ & \multirow[t]{6}{*}{40.4} & \\
\hline & Apricots 2 & $92.2 \pm 9.3$ & & \\
\hline & Apricots 3 & $13.5 \pm 0.3$ & & \\
\hline & Apricots 4 & $22.8 \pm 0.6$ & & \\
\hline & Apricots 5 & $<\mathrm{LOQ}$ & & \\
\hline & Apricots 6 & $13.6 \pm 0.3$ & & \\
\hline & Raisins 1 & $<$ LOQ & \multirow[t]{6}{*}{0.0} & \\
\hline & Raisins 2 & $<$ LOQ & & \\
\hline & Raisins 3 & n.d & & \\
\hline & Raisins 4 & $<$ LOQ & & \\
\hline & Raisins 5 & $<$ LOQ & & \\
\hline & Raisins 6 & n.d & & \\
\hline & Plums 1 & $28.4 \pm 1.4$ & \multirow[t]{6}{*}{$43.9^{\mathrm{a}}$} & \\
\hline & Plums 2 & $141 \pm 1$ & & \\
\hline & Plums 3 & $22.1 \pm 1.3$ & & \\
\hline & Plums 4 & $25.1 \pm 0.8$ & & \\
\hline & Plums 5 & $23.4 \pm 1.1$ & & \\
\hline & Plums 6 & $22.8 \pm 0.6$ & & \\
\hline & Cranberry 1 & n.d & \multirow[t]{6}{*}{0.0} & \\
\hline & Cranberry 2 & n.d & & \\
\hline & Cranberry 3 & n.d & & \\
\hline & Cranberry 4 & $<$ LOQ & & \\
\hline & Cranberry 5 & n.d & & \\
\hline & Cranberry 6 & $<$ LOQ & & \\
\hline \multirow[t]{15}{*}{ Smoked } & Pears 1 & $372 \pm 20.7$ & \multirow[t]{5}{*}{269.4} & \multirow[t]{15}{*}{$270.7^{\mathrm{d}}$} \\
\hline & Pears 2 & $696 \pm 55.8$ & & \\
\hline & Pears 3 & $59.2 \pm 0.7$ & & \\
\hline & Pears 4 & $59.8 \pm 6.0$ & & \\
\hline & Pears 5 & $160 \pm 2.3$ & & \\
\hline & Apple 1 & $0.0 \pm 0.0$ & \multirow[t]{5}{*}{140.3} & \\
\hline & Apple 2 & $234 \pm 15.3$ & & \\
\hline & Apple 3 & $19.6 \pm 0.1$ & & \\
\hline & Apple 4 & $48.8 \pm 3.7$ & & \\
\hline & Apple 5 & $399 \pm 19.7$ & & \\
\hline & Plums 1 & $558 \pm 9.3$ & \multirow[t]{5}{*}{$402.3^{\mathrm{b}}$} & \\
\hline & Plums 2 & $730 \pm 9.3$ & & \\
\hline & Plums 3 & $111 \pm 10.5$ & & \\
\hline & Plums 4 & $602 \pm 56.6$ & & \\
\hline & Plums 5 & $12.1 \pm 0.4$ & & \\
\hline
\end{tabular}

Mean values denoted by the different letters are statistically significant $(p<0.05)$

$A A$ acrylamide, $S D$ standard deviation, $L O Q$ limit of quantification, n.d. not detected 
growth, chemical reaction, and/or enzymatic activity. Fruits and vegetables are especially susceptible to these actions, since their initial water content ranged is from 74 to $90 \% \mathrm{w} / \mathrm{w}$ [32]. Hence, drying positively influence on fruits' and vegetables' shelf-life. Additionally, it can decrease the cost of food storage and transport, due to the loss of the original shape and weight. Nonetheless, despite these advantages, food drying might lead to the damage and severe changes in the physicochemical and organoleptic properties of the foodstuffs such as changes in flavour, colour, shrinkage and oxidation of fat and partial loss of nutrients [31,33].

On the other hand, smoking is the technological operation which not only inhibits the growth of microorganisms but is also used to provide an enhanced organoleptic profile to foodstuffs, including specific flavour, colour and aroma, which is highly by consumers [5]. A lot has been said about smoking food and many have been written, often fuelling fear with claims that smoked products are harmful for health. Smoke, as is known, is produced during incomplete combustion or the so-called dry distillation of wood and other vegetable derivatives. However, the most important thing is always how to do it. If the temperature of burning sawdust is too high or if the wrong raw materials are used, PAH concentrations increase significantly in the smoke. But on the other hand, in the smoke, the right amount of phenols is essential, necessary to improve the taste, fixation, and give an aesthetic colour to the smoked product, which is associated with the burning of sawdust at a higher temperature. Therefore, it is necessary to adopt a general rule that the temperature of burning or glowing of the smoke-producing material cannot exceed $500-600{ }^{\circ} \mathrm{C}$ [4].

\section{Conclusion}

To the best of our knowledge, the present paper is the first study concerning the level of thermal processing contaminants (PAHs, 3-MCPD and AA) in such a diversity of foodstuffs such as dried and smoked fruits. The obtained results, especially the content of PAHs in smoked fruits, underline the need for further research in this area and the necessity to set a maximum PAHs, 3-MCPD and AA content in dried and smoked fruit to protect human health. It also seems necessary to inform consumers about the potential health effects, resulting from regular consumption this type of foodstuffs.

Acknowledgements This research was performed with the financial support from Ministry of Science and Higher Education of Republic of Poland within the statutory R \& D activities (DS-3707/KTGiK/2017).

\section{Compliance with ethical standards}

Conflict of interest Magdalena Surma declares that she has no conflict of interest. Anna Sadowska-Rociek declares that she has no conflict of interest. Ewa Cieślik declares that she has no conflict of interest.
Ethical approval This article does not contain any studies with human participants or animals performed by any of the authors.

Informed consent Not applicable.

Open Access This article is distributed under the terms of the Creative Commons Attribution 4.0 International License (http://creativeco mmons.org/licenses/by/4.0/), which permits unrestricted use, distribution, and reproduction in any medium, provided you give appropriate credit to the original author(s) and the source, provide a link to the Creative Commons license, and indicate if changes were made.

\section{References}

1. Cross M (2015) Zdrowie na talerzu. Białystok, Vivante

2. Raghavan GSV, Orsat V (2007) Recent advances in drying of biomaterials for superior quality bioproducts. Asia Pac J Chem Eng 2:20-29

3. http://www.valleysun.com/process.html

4. Binder (2007) Wędzienie mięsa, kiełbas i ryb. Multico, Warszawa

5. Ledesma E, Rendueles M, Diaz M (2016) Contamination of meat products during smoking by polycyclic aromatic hydrocarbons: Processes and prevention. Food Control 60:64-67

6. http://www.chatawlesie.pl/tag/suszenie-wedzenie-owocow/

7. IARC Monographs on the evaluation of carcinogenic risks to humans (1994) International Agency for Research on Cancer. vol 60. France

8. IARC Monographs on the evaluation of carcinogenic risks to humans (2013) International Agency for Research on Cancer. vol 101. France

9. IARC Monographs on the evaluation of carcinogenic risks to humans (2010) International Agency for Research on Cancer. vol 92. France

10. IARC Monographs on the evaluation of carcinogenic risks to humans (2012) International Agency for Research on Cancer. vol 100F. France

11. Ma Y, Harrad S (2015) Spatiotemporal analysis and human exposure assessment on polycyclic aromatic hydrocarbons in indoor air, settled house dust, and diet: a review. Environ Int 84:7-16

12. Commission Regulation (EU) No 835/2011 amending Regulation (EC) No 1881/2006 as regards maximum levels for polycyclic aromatic hydrocarbons in foodstuffs (2011) Off J Eur Union L 215:4-8

13. Halmet CG, Sadd PA, Crews C, Velisek J, Baxter DE (2002) Occurrence of 3-chloro-propane-1,2-diol (3-MCPD) and related compounds in foods: a review. Food Addit Contam 19:619-631

14. Scientific Opinion (2016) Risks for human health related to the presence of 3- and 2-monochloropropanediol (MCPD), and their fatty acid esters, and glycidyl fatty acid esters in food. EFSA Panel on Contaminants in the Food Chain (CONTAM). EFSA J 14(5):4426

15. Mottram DS, Wedzicha BL, Dodson AT (2002) Acrylamide is formed in the Maillard reaction. Nature 419(6906):448-449

16. Zyzak DV, Sanders RA, Stojanovic M, Tallmadge DH, Eberhardt BL, Ewald DK (2003) Acrylamide formation mechanism in heated foods. J Agric Food Chem 51(16):4782-4787

17. Friedman M (2003) Chemistry, biochemistry, and safety of acrylamide. A review. J Agric Food Chem 51:16:4504-4526

18. Surma M, Sadowska-Rociek A, Cieślik E (2014) The application of d-SPE in the QuEChERS method for the determination of PAHs in food of animal origin with GC-MS detection. Eur Food Res Technol 238:1029-1036 
19. Sadowska-Rociek A, Cieślik E, Sieja K (2016) Simultaneous sample preparation method for determination of 3-monochloropropane-1,2-diol and polycyclic aromatic hydrocarbons in different foodstuffs. Food Anal Method 9:10:2906-2916

20. Surma M, Sadowska-Rociek A, Cieślik E (2016) Development of a sample preparation method for acrylamide determination in cocoa via sililation. Anal Methods 8:5874-5880

21. Paris A, Ledauphin J, Poinot P, Gaillard JL (2018) Polycyclic aromatic hydrocarbons in fruits and vegetable: origin, analysis, and occurrence. Environ Pollut 234:96-106

22. Commission Regulation (EU) No 2015/1125 amending Regulation (EC) No 1881/2006 as regards maximum levels for polycyclic aromatic hydrocarbons in Katsuobushi (dried bonito) and certain smoked Baltic herring (2015) Off J Eur Union L 184:7-10

23. Food Safety Authority in Ireland (2006) Investigation into levels of Polycyclic Aromatic Hydrocarbons (PAHs) in food on the Irish market. 1-30

24. EFSA/DATEX/002 (revision 1) (2008) A report from the unit of data collection and exposure on a request from the European Commission. Findings of the EFSA data collection on polycyclic aromatic hydrocarbons in food. EFSA 1-55

25. Scientific Report of EFSA (2013) Analysis of occurrence of 3-monochloropropane-1,2-diol (3-MCPD) in food in Europe in the years 2009-2011 and preliminary exposure assessment. EFSA J 11(9):3381

26. Commission Regulation (EU) No $2013 / 647$ on investigations into the levels of acrylamide in food (2013) Off J Eur Union L 301:15-17
27. De Paola EL, Montevecchi G, Masino F, Garbini D. Barbanera M, Antonelli A (2017) Determination of acrylamide in dried fruits and edible seeds using QuEChERS extraction and LC separation with MS detection. Food Chem 217:191-195

28. Žilić S (2016) In: Gökmen V (ed) Acrylamide in food acrylamide in soybean products, roasted nuts, and dried fruits, (pp 197-213) analysis, Content and Potential Health Effects. Elsevier Inc,

29. Becalski A, Lau BPY, Lewis D, Seaman SW (2011) Acrylamide in foods: occurrence, sources, and modeling. J Agric Food Chem 51:3:802-808

30. Kukurová K, Constatntin OE, Dubová Z, Tobolková B, Suhaj M, Nystazou Z, Rapeanu G, Ciesarová Z (2015) Acrylamide content and antioxidant capacity in thermally processed fruit products. Potraviniarstvo Sci J Food Ind 9:90-94

31. Ratti C (2001) Hot air and freeze-drying of high-value foods: a review. J Food Eng 49:311-319

32. Koszela K, Otrząsek J, Zaborowicz M, Boniecki P, Mueller W, Raba B, Lewicki A, Przybył K (2014) Quality assessment of microwave-vacuum dried material with the use of computer image analysis and neural model. Proc SPIE Int Soc Opt Eng 9159:1-9

33. An K, Zhao D, Wang Z, Wu J, Xu Y, Xiao G (2016) Comparison of different drying methods on Chinese ginger (Zingiber officinale Roscoe): Changes in volatiles, chemical profile, antioxidant properties, and microstructure. Food Chem 197:1292-1300 